\title{
Evaporative cooling for lactating sows under high ambient temperature
}

\author{
Charles Kiefer $^{1}$, Leandro Pereira Martins ${ }^{2}$, Caiki Calepso Fantini ${ }^{2}$
}

${ }^{1}$ FAMEZ/UFMS.

${ }^{2}$ Animal Science undergraduate course/UFMS.

\begin{abstract}
Two experiments were conducted to evaluate the evaporative cooling of the air at farrowing on the performance of lactating sows under high environmental temperature conditions in the Central West region of Brazil. One hundred and forty-four lactating sows - 46 of first and second farrowing (experiment I) and 98 from the third to eighth farrowing (experiment II) - were used. Sows were distributed in experimental design of randomized blocks consisting of two rooms (with air cooling and control), with the sow as the experimental unit. The average duration of lactation was 21 days. Sows were fed ad libitum with the same lactation diet. In experiment I, the air cooling increased the daily feed intake, reduced the total and percent weight loss, increased the weight of the piglets and litters at weaning and improved the daily milk production of sows. However, the air cooling did not affect the weight of the sows or the number of piglets at weaning. In experiment II the air cooling increased the daily feed intake of the sows, reduced the total and percent weight loss, increased the weight and the weight gain of the piglets and litters and improved the daily milk production of the sows. Air cooling enables the increase of the daily feed intake and, therefore, of nutrients by the sows, with consequent reduction of mobilization of body reserves and the increase in the milk production and in the weight of piglets and litters at weaning, regardless the farrowing order of the sow.
\end{abstract}

Key Words: environment, feed intake, milk production, piglets, weaning

\section{Introduction}

It has been observed that sows genetically modified through selection processes present reduced appetite and low feed intake capacity (Sauber et al., 1994; Eissen et al., 2000). In regions with predominance of high environmental temperatures, feed intake and milk production can also be reduced by the sows in order to avoid the increase of body temperature and thus maintain the thermal homeostasis (Quiniou \& Noblet, 1999; Renaudeau et al., 2001).

The low nutrients and feed intake may reflect in the increase of mobilization of body reserves during the lactation, considering the fact that feed intake is not enough to meet the nutrient requirements of an appropriate milk production. In turn, high losses of body reserves during lactation can increase the weaning-toestrus interval and reduce the size of the subsequent litter of the sows (Boyd et al., 2000), affecting the productivity of the farm.

The reduction in the milk production by the sows as a consequence of high ambient temperatures may also result in reduction of the weight gain of the piglets and litters, reducing significantly the weight of the piglets at weaning (Johnston et al., 1999; Quiniou \& Noblet, 1999; Renaudeau et al., 2001).
Research shows that the reduction in milk production by the sows is not always associated to reduction in feed intake. There is a direct effect of the ambient temperature on the milk production, in which the capacity of the lactating sow to mobilize and redistribute the nutrients from the reserve tissues to the mammary gland is impaired under high temperature conditions, either by the alteration of the endocrine functions, or by redirecting the blood flow to the body periphery to increase the body heat loss (De Bragança et al., 1998).

Other studies have concluded that the apparent inefficiency of the mammary glands of lactating sows maintained under high ambient temperatures may be related to the increased proportion of blood flow destined to the irrigation of the skin capillaries in order to dissipate the body heat (Renaudeau et al., 2003). Thus, the dietary nutrients and those mobilized from the body reserves are often insufficient to meet the milk production and maintain the body condition of the sows under such environmental conditions.

Studies suggest that a high quality diet to the lactating sows will not be sufficient to maintain the reproductive and productive performance under adverse environmental conditions (De Bragança et al., 1998; Renaudeau et al., 2003), requiring the implementation of secondary 
$(\mathrm{kg} /$ day $)=[(4.27 \times$ weight gain of the piglet in the period, $\mathrm{kg})$ $\times$ number of piglets]/number of lactation days.

The collected data were submitted to analysis of variance through the GLM procedure of the statistical software SAS (Statistical Analysis System, version 8.2) at the significance level of 0.05 .

\section{Results and Discussion}

During the experimental period, the air temperature of the rooms was $29.4 \pm 2.6^{\circ} \mathrm{C}$, the relative humidity of the air was $85.4 \pm 16.5 \%$ and the black globe temperature was $30.2 \pm 2.9^{\circ} \mathrm{C}$. Considering that the zone of thermoneutrality for the lactating sows is characterized by temperatures ranging between 16 and $22^{\circ} \mathrm{C}$ (Black et al., 1993; De Bragança et al., 1998) and based on the thermal variation during the experimental period, it is possible to conclude that the sows were subjected to heat stress.

The GTHI calculated during the experimental period

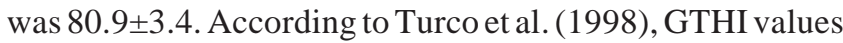
above 72 increase the respiratory rate and the rectal temperature of the lactating sows and indicate the occurrence of discomfort and thermal stress. Thus, the GTHI value observed in this study characterizes the environment as heat stressing.
In experiment I, effect $(\mathrm{P}<0.01)$ of the cooling of the air was verified on the daily feed intake, in which the sows kept under cooling presented higher daily intake in comparison with the control group (Table 2). When comparing the intake pattern of the sows (Figure 1), both the groups presented similar quadratic responses in relation to the daily feed intake throughout the 21 days of lactation, reaching the peak of consumption at 15.8 days.

The higher daily feed intake observed for the sows subjected to air cooling is probably related to the improvement of the temperature gradient between the sow

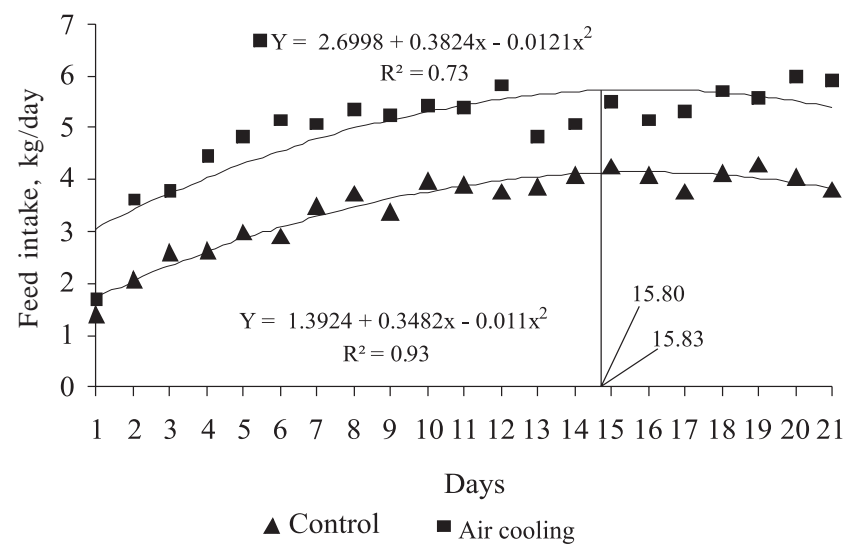

Figure 1 - Profile daily feed intake of sows of first and second farrowing order according to thermal environment.

Table 2 - Performance of sows of first and second farrowing order and their litters according to the environment

\begin{tabular}{|c|c|c|c|c|}
\hline \multirow[t]{2}{*}{ Variables } & \multicolumn{2}{|c|}{ Environment } & \multirow[t]{2}{*}{ CV (\%) } & \multirow[t]{2}{*}{$\mathrm{P}$ value } \\
\hline & Control & Air cooling & & \\
\hline Sows, number & 22 & 24 & & \\
\hline Lactation, days & $20.91 \pm 0.30$ & $21.54 \pm 0.66$ & & \\
\hline Daily feed intake, kg & 3.36 & 5.03 & 22.48 & $<0.001$ \\
\hline \multicolumn{5}{|l|}{ Weight } \\
\hline \multicolumn{5}{|l|}{ Weight variation } \\
\hline Kg & -19.17 & -2.28 & 12.78 & $<0.001$ \\
\hline$\%$ & -9.23 & -1.31 & 12.59 & $<0.001$ \\
\hline \multicolumn{5}{|l|}{ Number of pigs } \\
\hline 24 hours postpartum & 12.00 & 11.17 & 9.54 & 0.221 \\
\hline 24 hours postpartum, kg & 1.26 & 1.40 & 33.37 & 0.302 \\
\hline At weaning, kg & 4.59 & 5.87 & 20.28 & $<0.001$ \\
\hline \multicolumn{5}{|l|}{ Weight of litters } \\
\hline 24 hours postpartum, kg & 15.06 & 15.40 & 31.52 & 0.822 \\
\hline At weaning, $\mathrm{kg}$ & 50.00 & 59.04 & 25.53 & 0.048 \\
\hline \multicolumn{5}{|l|}{ Daily weight gain } \\
\hline Piglets, g & 151 & 206 & 25.24 & $<0.001$ \\
\hline Litters, kg & 1.66 & 2.08 & 31.21 & 0.032 \\
\hline Daily milk production, kg & 7.42 & 9.14 & 29.75 & 0.032 \\
\hline
\end{tabular}


and the environment because of the increase in the efficiency of loss of body sensible heat to the environment, allowing the maintenance of the homeothermy. Similar results were observed by De Bragança et al. (1998), Quiniou \& Noblet (1999) and Renaudeau et al. (2001, 2003) who also observed a reduction in the voluntary feed intake in order to reduce the production of heat generated by feed in lactating sows exposed to environmental temperatures of $30,29,29$ and $28^{\circ} \mathrm{C}$, respectively.

There was no effect $(\mathrm{P}>0.05)$ of the air conditioning on the weight of the sows at weaning. However, effect $(\mathrm{P}<0.01)$ of the air conditioning was verified on the variation of weight, in which the sows subjected to evaporative cooling mobilized substantially less body tissues, with loss of $2.28 \mathrm{~kg}$, which represents $1.31 \%$ of the initial weight. In turn, the sows subjected to a non-cooled environment presented weight loss of $19.17 \mathrm{~kg}$, representing a percentage of loss of $9.23 \%$ in relation to the initial body weight.

It is possible to conclude that the result obtained in this study in relation to the reduction of mobilization of body tissues of the sows subjected to cooling during the lactation is probably related to the increase in feed intake. This response is positive, considering that the sows of first and second farrowing are in process of growth and the reduction of weight loss can enable the maintenance of high patterns of reproductive and productive performances in the subsequent cycles.

In turn, Silva et al. (2006), when assessing the cooling of the floor for lactating sows, observed that cooling caused an increase in the daily feed intake $(6.47 \times 5.61 \mathrm{~kg})$, but the sows kept in cold floor presented significantly higher loss of body protein and weight. The researchers attributed this fact to the increase in the capacity of milk production of these animals. Lima et al. (2011) also found that lactating sows housed on cooled floor and fed ad libitum presented higher daily feed intake in relation to the group maintained without the cooling of the floor $(6.08 \times$ $4.86 \mathrm{~kg}$ ); however the mobilizations of body fat and protein were not affected.

There was no effect $(\mathrm{P}>0.05)$ of the environment on the number of piglets at weaning. The mortality rate of the piglets in the course of lactation was not affected $(\mathrm{P}>0.05)$ by the environment, either. However, the litters of the sows subjected to cooling presented a reduction of $1.8 \%$ in the mortality rate of the piglets.

The cooling of the air resulted in increase $(\mathrm{P}<0.05)$ of weight of the piglets and litters at weaning. Higher $(\mathrm{P}<0.05)$ daily weight gain was also observed in the piglets and litters of the sows subjected to cooling in relation to the control group. These results may be justified by the increase
$(\mathrm{P}<0.05)$ in the daily milk production estimated for the sows subjected to air cooling in relation to the control group.

According to Prunier et al. (1997), the environmental temperature (18 versus $27^{\circ} \mathrm{C}$ ) does not affect the percentage of dry matter, protein, fat and gross energy of the colostrum and milk of sows. However, these researchers verified that the weight gain of the piglets is significantly reduced under a temperature of $27^{\circ} \mathrm{C}$, allowing us to conclude that the milk production is also reduced under this condition. Similarly, Renaudeau \& Noblet (2001) verified that high environmental temperature $\left(29^{\circ} \mathrm{C}\right)$ impairs the milk production of the sows and the performance of the piglets and litters in comparison with the thermal comfort temperature $\left(20^{\circ} \mathrm{C}\right)$. These same researchers found that it was not possible to reduce the harmful effect of high temperature by manipulating the composition of the diet of the sows. These findings point out the need to perform environmental adjustments, such as the cooling of the air, to improve the productive performance of the sows and their litters.

In experiment II, effect $(\mathrm{P}<0.01)$ of the environment was observed on the feed intake, in which the sows subjected to air cooling presented a higher daily feed intake in relation to the control group $(5.71 \times 4.56 \mathrm{~kg} /$ day $)$ (Table 3$)$. The analysis of the intake pattern of the sows (Figure 2) showed that both the groups presented similar quadratic responses in relation to daily feed intake in the course of the lactation period, when the peak of intake was reached at 14.6 and 14.7 days for the sows subjected to the cooling system and the control group, respectively. The graphical representation allows us to conclude that despite the similar feed intake pattern observed, the higher intake of the sows subjected to cooling remains constant in the course of the experimental period.

There was no effect $(\mathrm{P}>0.05)$ of the air cooling on the weight of the sows at weaning. However, effect $(\mathrm{P}<0.01)$ of the cooling of the air was verified on the variation of absolute and percent weights, in which the sows kept under cooling maintained their weight virtually constant during the lactation period (weight gain of 80 grams in 21 days of lactation), while the sows kept in a noncooled environment presented weight loss of $17.71 \mathrm{~kg}$, representing a mobilization of $6.68 \%$ of the body tissues in relation to the post-farrow weight.

Considering the fact that the air cooling provided sows with intake differential higher than $1 \mathrm{~kg}$ per day, the variance between gain and loss of weight observed between the groups of sows subjected to cold and control environments can probably be justified by the feed intake variable. This intake differential observed may indicate that the quantity of ingested feed met the nutritional requirements of the 
Table 3 - Performance of sows of third to eighth farrowing order and their litters according to the environment

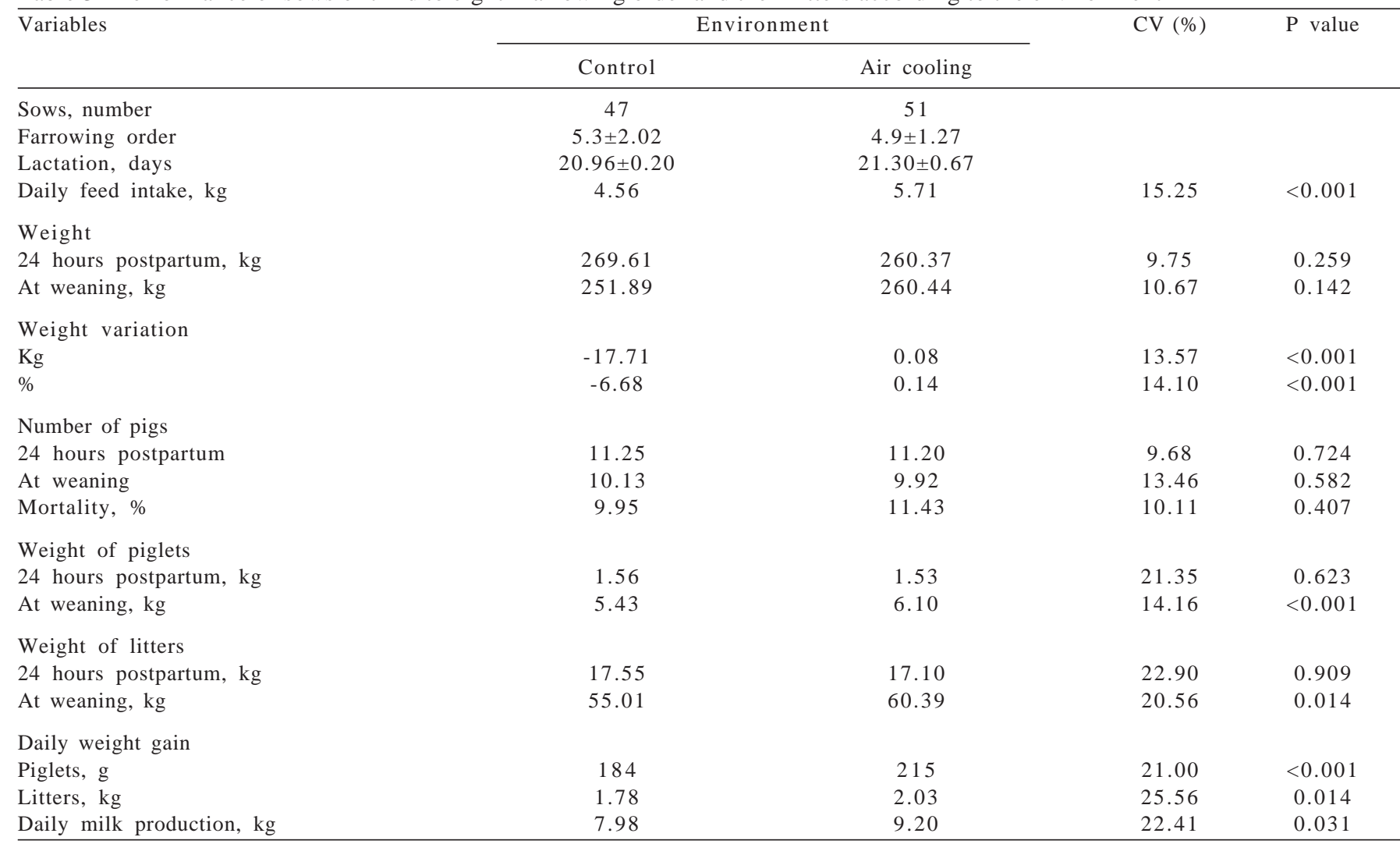

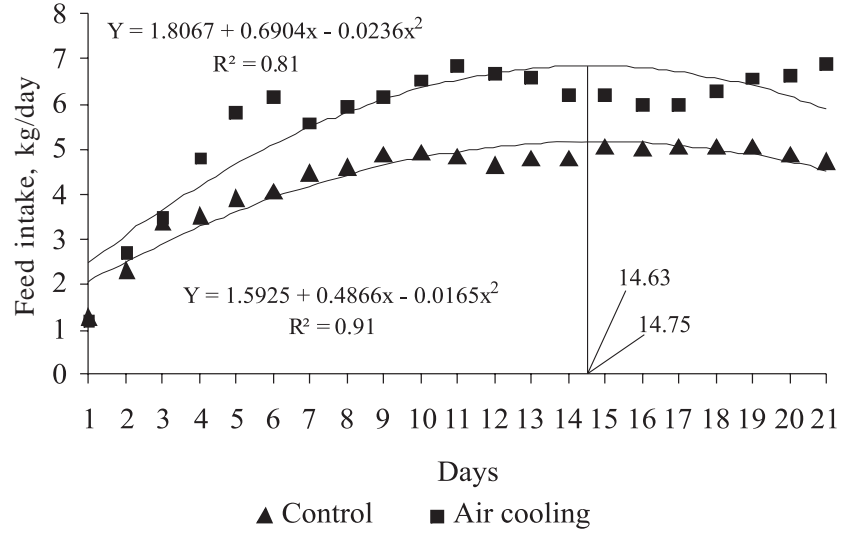

Figure 2 - Profile daily feed intake of sows of third to eighth farrowing order according to thermal environment.

sows both for the maintenance and for the milk production. Thus, there was no mobilization of body tissues.

According to Clowes et al. (2003), sows can maintain their regular milk production and reproductive functions even in case of moderate weight loss in the course of lactation. The same researchers found that the relative decrease in the performance of the sows is directly related to the mobilization of body protein, and that mobilizations of up to $9 \%$ of the body protein mass do not present a negative effect on the growth of piglets and litters.
In turn, there was a mobilization higher than $9 \%$ of the body protein mass of the sows subjected to the non-cooled environment, probably due to the fact that the animals used in the present study had a high genetic potential associated to a high body weight loss $(17.71 \mathrm{~kg})$ in the course of lactation. This fact undermined the productive performance of the sows and their litters.

There was no effect $(\mathrm{P}>0.05)$ of the environment on the number of piglets at weaning and on the mortality rate of piglets in the course of lactation. However, the cooling of the air resulted in increase $(\mathrm{P}<0.05)$ of weight gain of the piglets and litters and, therefore, in the weight of piglet and litter at weaning.

The results obtained in the present study allow us to conclude that the cooling of the air was found to be efficient, since it reduced the negative effect of the high air temperature on the sows and allowed a weight gain of the litters $(2.03 \mathrm{~kg} /$ day) similarly to the weight gain observed in research studies that contrasted stress by heat and comfort air temperatures for lactating sows. Among these studies, Johnston et al. (1999) stressed weight gain of $2.11 \mathrm{~kg} /$ day for the litters of sows kept in thermal comfort environment $\left(17.7^{\circ} \mathrm{C}\right)$ and a gain of $1.74 \mathrm{~kg} /$ day for the litters of sows kept under stress by heat $\left(27.1^{\circ} \mathrm{C}\right)$. On the other hand, higher 
variances in relation to the weight gain of the litters observed in the present study were found by Quiniou \& Noblet (1999), who obtained a gain of $1.94 \mathrm{~kg} /$ day for litters of sows maintained in high temperature environment $\left(29^{\circ} \mathrm{C}\right)$ while the litters of sows maintained under thermal comfort $\left(18^{\circ} \mathrm{C}\right)$ presented a gain of $2.46 \mathrm{~kg} /$ day. Renaudeau et al. (2001) also (1999) pointed out a weight gain of $2.93 \mathrm{~kg} /$ day for litters of sows kept in thermal comfort $\left(20^{\circ} \mathrm{C}\right)$ in comparison with the gain of $2.15 \mathrm{~kg} /$ day for the litters of sows kept under high temperature $\left(29^{\circ} \mathrm{C}\right)$.

The environment affected $(\mathrm{P}<0.05)$ the estimated daily milk production, in which the sows subjected to cooling of the air presented a higher daily production in comparison with the sows subjected to the control environment. The estimated daily milk productions, with values of 7.98 and $9.20 \mathrm{~kg} /$ day for the sows without and with air cooling, respectively, can be considered lower than those recommended as the ideal for high genetic potential animals, since high potential contemporary sows can reach an estimated daily production above $10 \mathrm{~kg}$ of milk, considering a lactation period of 21 days and a conversion of 4 grams of milk per gram of weight gain of the litter (Boyd et al., 2000). However, since the environmental temperatures registered during the experimental period were high $\left(29.4^{\circ} \mathrm{C}\right)$, the milk production estimated in this study can be considered satisfactory. Moreover, the results of milk production obtained are above the values of 6.18 and $7.25 \mathrm{~kg} / \mathrm{day}$ estimated by Quiniou \& Noblet (1999) and Renaudeau et al. (2001), respectively, for lactating sows maintained in temperature conditions similar to the conditions of this study $\left(29^{\circ} \mathrm{C}\right)$.

It is possible to conclude that the improvement in the performance of the piglets observed for the sows subjected to air cooling in the present study is directly related to the increase in the milk production and feed intake. These results are consistent with those observed by De Bragança et. al. (1998) and Renaudeau et al. (2003), who also observed that the milk production and the performance of the piglets and litters are associated to the environmental thermal condition under which the sows are maintained.

\section{Conclusions}

The evaporative cooling of the air allows the increase of daily feed intake and, therefore, of nutrients by the sows, enabling the reduction in the mobilization of body reserves and the increase in the milk production during lactation, in addition to increase in the weight of piglets and litters at weaning, regardless of the farrow order of the sow.

\section{References}

BLACK, J.L.; MULLAN, M.L.; LORSCHY, M.L. et al. Lactation in the sow during heat stress. Livestock Production Science, v.35, p.153-170, 1993.

BOYD, R.D.; TOUCHETTE, K.J.; CASTRO, G.C. et al. Recent advances in amino acid and energy nutrition of prolific sows: Review. Journal of Animal Science, v.13, p.1638, 2000.

BUFFINGTON, D.E.; COLAZO-AROCHO, A.; CANTON, G.H. et al. Black globe humidity index (BGHI) as comfort equation for dairy cows. Transaction of American Society of Agricultural Engineering, v.24, p.711-714, 1981.

CLOWES, E.J.; AHERNE, F.X.; FOXCROFT, G.R. et al. Selective protein loss in lactating sows is associated with reduced litter growth and ovarian function. Journal of Animal Science, v.81, p.753-764, 2003.

DE BRAGANÇA, M.M.; MOUNIER, M.; PRUNIER, A. Does feed restriction mimic the effects of increased ambient temperature in lactating sows? Journal of Animal Science, v.76, p.2017-2024, 1998.

EISSEN, J.J.; KANIS, E.; KEMP, B. Sow factors affecting voluntary feed intake during lactation Livestock Production Science, v.64, p.147-165, 2000.

FERREIRA, A.S.; COSTA, P.M.A.; PERREIRA, J.A.A. et al. Estimativas de produção de leite de porca. Revista da Sociedade Brasileira de Zootecnia, v.17, p.203-211, 1988.

JOHNSTON, L.J.; ELLIS, M.; LIBAL, G.W. et al. Effect of room temperature and dietary amino acid concentration on performance of lactating sows. Journal of Animal Science, v.77, p.1638-1644, 1999.

LIMA, A.L.; OLIVEIRA, R.F.M.; DONZELE, J.L. et al. Resfriamento do piso da maternidade para porcas em lactação no verão. Revista Brasileira de Zootecnia, v.40, p.804-811, 2011.

PRUNIER, A.; DE BRAGANÇA, M.M.; LE DIVIDICH, J. Influence of high ambient temperature on performance reproductive sows. Livestock Production Science, v.52, p.123-133, 1997.

QUINIOU, N.; NOBLET, J. Influence of high ambient temperatures on performance of multiparous lactating sows. Journal of Animal Science, v.77, p.2124-2134. 1999.

RENAUDEAU, D.; NOBLET, J.; DOURMAD, J.Y. Effect of ambient temperature on mammary gland metabolism in lactating sows. Journal of Animal Science, v.81, p.217-231. 2003.

RENAUDEAU, D.; NOBLET, J. Effects of exposure to high ambient temperature and dietary protein level on sow milk production and performance of piglets. Journal of Animal Science, v.79, p.1540-1548, 2001.

RENAUDEAU, D.; QUINIOU, N.; NOBLET, J. Effects of exposure to high ambient temperature and dietary protein level on performance of multiparous lactating sows. Journal of Animal Science, v.79, p.1240-1249, 2001.

ROSTAGNO, H.S.; ALBINO, L.F.T.; DONZELE, J.L. et al. Composição de alimentos e exigências nutricionais: tabelas brasileiras para aves e suínos. Viçosa, MG: Universidade Federal de Viçosa, 2005. 186p.

SARTOR, V.; BAÊTA, F.C.; TINÔCO, I.F.F. et al. Efeito do resfriamento evaporativo no desempenho de suínos em fase de terminação. Engenharia na Agricultura, v.11, p.58-64, 2003.

SAUBER, T.E.; STAHLY, T.S.; EWAN, R.C. et al. Interactive effects of sow genotype and dietary amino acid intake on lactational performance of sows nursing large litters. Journal of Animal Science, v.72 (suppl.2), p.66 (Abstr.), 1994.

SILVA, B.A.N.; OLIVEIRA, R.F.M.; DONZELE, J.L. et al. Effect of floor cooling on performance of lactating sows during summer. Livestock Science, v.105, p.176-184, 2006.

TURCO, S.H.N.; FERREIRA, A.S.; BAÊTA, F.C. et al. Avaliação térmica ambiental de diferentes sistemas de acondicionamento em maternidades suinícolas. Revista Brasileira de Zootecnia, v.27, p.974-981, 1998. 